\title{
Nitrogen fixation in the western equatorial Pacific: Rates, diazotrophic cyanobacterial size class distribution, and biogeochemical significance
}

\author{
Sophie Bonnet, ${ }^{1,2}$ Isabelle C. Biegala, ${ }^{3}$ Pierre Dutrieux, ${ }^{4}$ Lia O. Slemons, ${ }^{5}$ \\ and Douglas G. Capone ${ }^{1}$
}

Received 8 December 2008; revised 21 March 2009; accepted 1 April 2009; published 14 August 2009.

[1] A combination of ${ }^{15} \mathrm{~N}_{2}$ labeling, Tyramide Signal Amplification-Fluorescent

in Situ Hybridization (TSA-FISH) assay, and chemical analyses were performed along a trophic gradient $(8000 \mathrm{~km})$ in the equatorial Pacific. Nitrogen fixation rates were low $\left(0.06 \pm 0.02\right.$ to $\left.2.8 \pm 2.1 \mathrm{nmol} \mathrm{L}^{-1} \mathrm{~d}^{-1}\right)$ in HNLC waters, higher in the warm pool $\left(0.11 \pm 0.0\right.$ to $\left.18.2 \pm 2.8 \mathrm{nmol} \mathrm{L}{ }^{-1} \mathrm{~d}^{-1}\right)$, and extremely high close to Papua New Guinea $\left(38 \pm 9\right.$ to $\left.610 \pm 46 \mathrm{nmol} \mathrm{L}^{-1} \mathrm{~d}^{-1}\right)$. Rates attributed to the $<10-\mu \mathrm{m}$ fraction accounted for $74 \%$ of total activity. Both unicellular and filamentous diazotrophs were detected and reached 17 cells $\mathrm{mL}^{-1}$ and 1.85 trichome $\mathrm{mL}^{-1}$. Unicellular diazotrophs were found to be free-living in $<10-\mu \mathrm{m}$ fraction or in association with mucilage, particles, or eukaryotes in the $>10-\mu \mathrm{m}$ fraction, leading to a possible overestimation of this fraction to total $\mathrm{N}_{2}$ fixation. In oceanic waters, $98 \%$ of the unicellular diazotrophs were picoplanktonic. Finally, we found a clear longitudinal pattern of niche partitioning between diazotroph groups: while unicellular diazotrophs were present all along the transect, Trichodesmium spp. were detected only in coastal waters, where nitrogen fixation associated to both size fractions was greatly stimulated.

Citation: Bonnet, S., I. C. Biegala, P. Dutrieux, L. O. Slemons, and D. G. Capone (2009), Nitrogen fixation in the western equatorial Pacific: Rates, diazotrophic cyanobacterial size class distribution, and biogeochemical significance, Global Biogeochem. Cycles, 23, GB3012, doi:10.1029/2008GB003439.

\section{Introduction}

[2] The equatorial Pacific is the largest natural source of $\mathrm{CO}_{2}$ to the atmosphere [Tans et al., 1990] and contributes significantly to global new production [Chavez and Barber, 1987]. This region is marked by highly diverse ecosystems and divides in two main subregions: the eastern equatorial cold tongue and the western warm pool, which are dynamically and biogeochemically distinct. The eastern equatorial cold tongue is characterized by High-Nutrient, Low-Chlorophyll (HNLC) waters, where the low dissolved iron concentrations impose a first-order control on biological production of small phytoplankton [Martin et al., 1994] and grazing maintains low standing stocks of larger phytoplankton [Cullen, 1995]. Nutrients are upwelled to the surface and constitute the primary source of nitrate

\footnotetext{
${ }^{1}$ Wrigley Institute for Environmental Studies, University of Southern California, Los Angeles, California, USA

${ }^{2}$ Now at Laboratoire d'Océanographie, Physique et Biogéochimie, Faculté des Sciences de Luminy, Université de la Méditerranée-AixMarseille II, Institut de Recherche pour le Développement, UR167, CYROCO, CNRS, Marseille, France.

${ }^{3}$ Centre d'Océanologie de Marseille, Institut de Recherche pour le Développement, UR103 CAMELIA, Marseille, France.

${ }_{5}^{4}$ SOEST, University of Hawaii, Honolulu, Hawaii, USA.

${ }^{5}$ School of Oceanography, University of Washington, Seattle, Washington, USA.
}

Copyright 2009 by the American Geophysical Union. 0886-6236/09/2008GB003439\$12.00
[Toggweiler and Carson, 1995]; this source of nutrients maintains high "new" primary productivity [Le Bouteiller et al., 2003; Aufdenkampe et al., 2002], which accounts for 20 to $50 \%$ of global new production [Chavez and Barber, 1987]. Moreover, the wind-driven upwelling forms a characteristic tongue of cold waters centered just south of the equator. The western part of the equatorial Pacific (the Western Pacific Warm Pool) is characterized by the highest mean annual sea surface temperatures on Earth ranging from $28^{\circ} \mathrm{C}$ to greater than $29.5^{\circ} \mathrm{C}$ and by a deep sharp thermocline. In contrast to the eastern equatorial Pacific, new primary production is low $\left(\sim 15 \mathrm{~g} \mathrm{C} \mathrm{m}^{-2} \mathrm{a}^{-1}\right)$ and cannot be sustained by upwelled nitrogen [Peña et al., $1994]$ as a result of the strongly stratified water column.

[3] Recent data based on nitrogen isotopic ratios $\left(\delta^{15} \mathrm{~N}\right)$ of settling particles indicate a clear decreasing gradient of $\delta^{15} \mathrm{~N}$ when transitioning from HNLC waters to the western warm pool [Yoshikawa et al., 2005]. These observations indicate that new production is fueled by upwelled nitrate in the HNLC waters and probably to an increasing extent by nitrogen fixation in the warm pool. On the basis of total organic nitrogen measurements, Hansell and Feely [2000] concluded that nitrogen fixation must occur in the warm pool, but to date, no direct measurements of nitrogen fixation rates are available in this area. The nitrogendepleted environments such as the warm pool and the vast oceanic gyres are commonly thought as ideal ecological niches for nitrogen-fixing organisms [e.g., Karl, 2002]. In 
the northern subtropical and tropical Atlantic ocean, the amount of new nitrogen provided by $\mathrm{N}_{2}$ fixation is estimated to represent $50-180 \%$ of the flux of $\mathrm{NO}_{3}^{-}$into the euphotic zone [e.g., Capone et al., 2005], indicating that a major fraction of new primary productivity may be fueled by $\mathrm{N}_{2}$ fixation, rather than $\mathrm{NO}_{3}^{-}$diffusing from deeper layers or upwelled into the euphotic zone.

[4] A large effort has been dedicated to marine nitrogen fixation over the past several decades. Much of this research has focused exclusively on the cyanobacterium Trichodesmium [Carpenter, 1983]; it has been calculated that this large filamentous cyanobacterium recovered in the $>10-\mu \mathrm{m}$ fraction could be responsible for up to half of estimated marine nitrogen fixation [Capone et al., 1997; Gruber and Sarmiento, 1997]. More recently, unicellular coccoid cyanobacteria detected in the subtropical North Pacific (fraction $<10 \mu \mathrm{m}$ ) have been found to express the nifH gene, one of the structural genes encoding the enzyme complex nitrogenase, which catalyzes the process of nitrogen fixation [Zehr et al., 2001; Church et al., 2008]. Montoya et al. [2004] measured nitrogen fixation rates by organisms $<10 \mu \mathrm{m}$ that were similar to or could at times exceed rates by organisms recovered in the larger size fraction $(>10 \mu \mathrm{m})$. Unicellular diazotrophic cyanobacteria have been described so far to be of nanoplanktonic size $(3-10 \mu \mathrm{m})$ and to be related to Crocosphaera or Cyanothece [Zehr et al., 2001; Church et al., 2005; Foster et al., 2006]. However, high concentrations of diazotrophic picocyanobacteria have been recently detected in the southwest Pacific and in the Mediterranean Sea, where they dominated the photosynthetic diazotroph community [Biegala and Raimbault, 2008; Le Moal and Biegala, 2009]. These organisms are potentially related to uncultivated group A [Zehr et al., 2008].

[5] It is still unclear how ecological factors control nitrogen fixation in the ocean. Because diazotrophs are able to grow in nitrogen-depleted environments, other macronutrients and micronutrients such as phosphorus [e.g., Sañudo-Wilhelmy et al., 2001; Moutin et al., 2005; Sohm et al., 2008] or iron [Raven, 1988; Kustka et al., 2003] have been suggested to control this process. Other factors such as temperature [e.g., Staal et al., 2003] or $\mathrm{CO}_{2}$ [Hutchins et al., 2007] may also play a role. It is possible that several of these factors may simultaneously influence $\mathrm{N}_{2}$ fixation in the ocean [Mills et al., 2004] and that the nature of limitation of diazotrophy changes over time and space and/or that different diazotrophs predominate in different ecological niches defined by these environmental factors.

[6] During the Iron in the Equatorial Undercurrent (EUCFe) cruise (August-September 2006), we had the opportunity to study nitrogen fixation along a longitudinal transect in the equatorial Pacific (Figure 1), exhibiting strong temperature, nitrate, phosphate, and iron gradients. The objectives of this study were (1) to determine the bulk nitrogen fixation rates along the transect, (2) to determine the relative importance of the large $(>10 \mu \mathrm{m})$ and the small $(<10 \mu \mathrm{m})$ size fractions to the bulk nitrogen fixation, (3) to count and characterize the size class diversity of unicellular cyanobacterial diazotrophs using whole cell molecular techniques, and (4) to calculate the contribution of fixed dinitrogen to the nitrogen budget of the central/western equatorial Pacific.

\section{Materials and Methods}

[7] This research was carried out onboard the R/V Kilo Moana in the framework of the EUC-Fe operation (http:// www.ocean.washington.edu/cruises/KiloMoana2006/ index.html). The cruise started in Hawaii on 15 August 2006 and ended in Papua New Guinea on 30 September 2006. The sampling started on the equator at $140^{\circ} \mathrm{W}$ and ended on $145^{\circ} \mathrm{E}$, after crossing the International Date Line (Figure 1).

\subsection{Chlorophyll $a$, Nitrate, and Phosphate}

[8] At every equatorial station, vertical profiles $(0-150 \mathrm{~m})$ of temperature, nitrate, phosphate, and chlorophyll $a$ concentrations were obtained. For chlorophyll $a$ analysis, $2.8 \mathrm{~L}$ of seawater were filtered onto $\mathrm{GF} / \mathrm{F}$ filters. Chlorophyll $a$ was extracted overnight using acetone and analyzed fluorometrically. Nitrate and phosphate concentrations were determined onboard using a Technicon Autoanalyser II [Tréguer and Le Corre, 1975]. The detection limit was 0.03 and $0.02 \mu \mathrm{mol} \mathrm{L}^{-1}$ for nitrate and phosphate, respectively.

\subsection{Nitrogen Fixation Measurements}

\subsubsection{Routine Sampling}

[9] Rates of nitrogen fixation were measured using the ${ }^{15} \mathrm{~N}_{2}$ tracer method [Montoya et al., 1996]. All collection and incubation steps were carried out using strict trace metal clean conditions, with the exception of the test experiment described below. Water samples were collected using Teflonlined General Oceanics (Go-Flo) bottles at 15 stations (Figure 1), including 13 oceanic stations along the equatorial transect (stations 2 to 27) and two coastal stations located close to the Papua New Guinea coast (stations 29 and 30). Among the 15 stations, 9 were "long stations" (24 h) and 7 were "short stations" (4 h). For each "long station," nitrogen fixation rates have been measured at four depths $(50 \%, 10 \%, 1 \%$, and $0.1 \%$ surface light levels); for each "short station," they were performed only at one depth (50\% surface light level). Nitrogen fixation rates measurements were performed in acid-washed $(\mathrm{HCl}$ Suprapur, Merck) 4.5-L polycarbonate bottles equipped with septum caps to which additions of $3 \mathrm{~mL}$ of ${ }^{15} \mathrm{~N}_{2}$ gas $(99 \%$, Cambridge Isotopes) were made using a gas-tight syringe. Samples were incubated for $24 \mathrm{~h}$ in on-deck incubators with circulating seawater at the specified irradiances using blue screening. Incubations were terminated by gently filtering samples: for each depth, two replicates were filtered onto precombusted $\mathrm{GF} / \mathrm{F}$ filters $(0.7-\mu \mathrm{m}$ pore size) for determination of the "bulk" nitrogen fixation; two more replicates per depth were size-fractionated: they were prefiltered onto $10-\mu \mathrm{m}$ polycarbonate filters (washed onto a $\mathrm{GF} / \mathrm{F}$ precombusted filters) for fraction $>10 \mu \mathrm{m}$, while the filtrate was collected onto a precombusted $\mathrm{GF} / \mathrm{F}$ filter for the $<10-\mu \mathrm{m}$ fraction $(0.7-\mu \mathrm{m}$ pore size). Sample filters were dried at $60^{\circ} \mathrm{C}$, then stored over desiccant until analyzed by continuous-flow isotope ratio mass spectrometry with a 


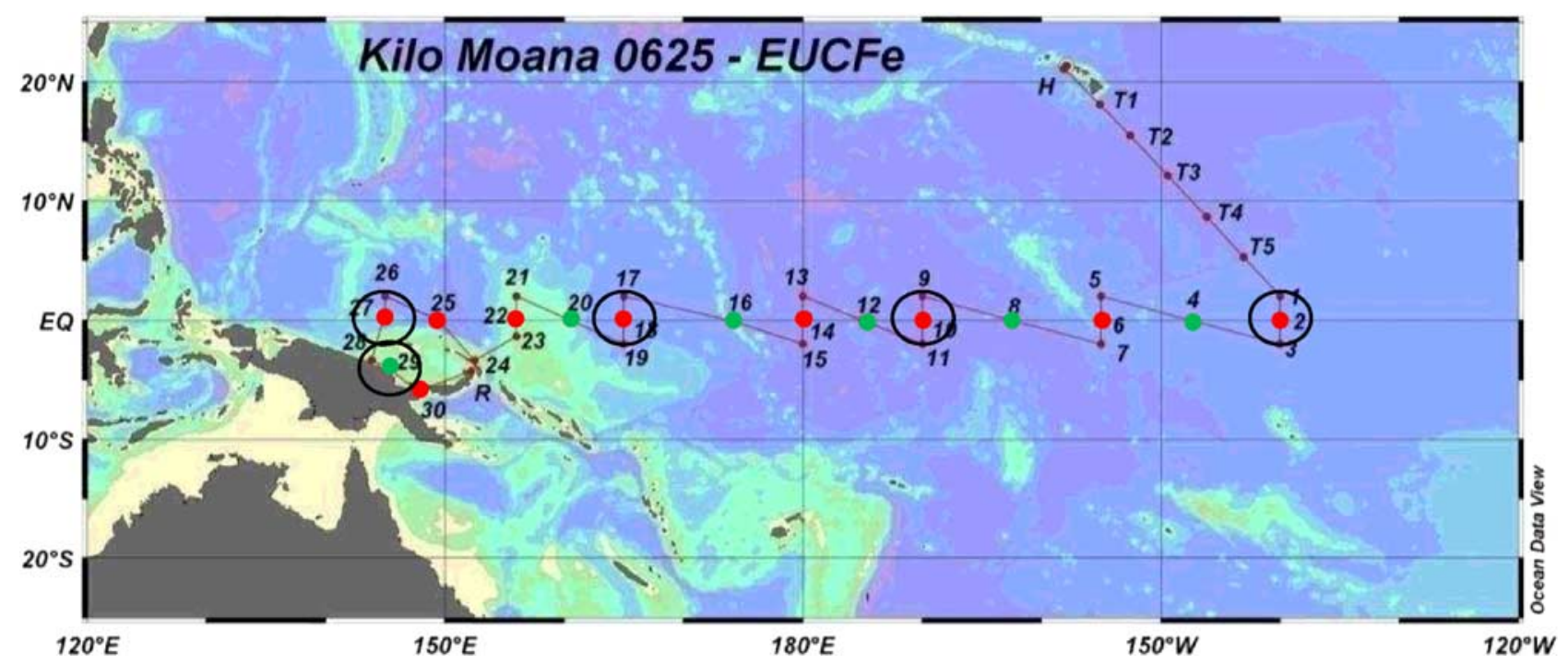

Figure 1. Transect of the Equatorial Undercurrent (EUC)-Fe cruise from Hawaii to Papua New Guinea (August-September 2006) and location of the long stations (red dots) and short stations (green dots) (T1 to T5: transect stations from Hawaii to $140^{\circ} \mathrm{W}$; no sampling authorized onboard). The black circles represent the stations sampled for Tyramide Signal Amplification-Fluorescent in Situ Hybridization (TSA-FISH) analysis.

Europa Integra continuous-flow mass spectrometer. $\mathrm{N}_{2}$ fixation rates were calculated by isotope mass balanced as described by Montoya et al. [1996]. Areal rate calculations were made only at the "long stations," where vertical profiles were available.

\subsubsection{Trace Metal Clean Sampling Versus "Regular" Sampling}

[10] In order to evaluate the impact of metal contamination on nitrogen fixation rates, the same vertical profile was determined using both trace metal clean conditions and nontrace-metal clean ("regular") conditions. At one selected station located in the warm pool (station 25), two CTD casts were performed at the same time using either the regular rosette equipped with Niskin bottles or the powder-coated rosette equipped with Teflonlined Go-Flo bottles. In the non-trace-metal sampling, three 4.5-L polycarbonate bottles (washed with regular $\mathrm{HCl}$ ) per depth $(5 \mathrm{~m}, 25 \mathrm{~m}$, and $67 \mathrm{~m}$ ) were drawn from the regular rosette on the deck using silicon tubing. In the trace metal sampling, three polycarbonate 4.5-L bottles (washed using Suprapur MERCK $\mathrm{HCl}$ ) were drawn from the trace metal clean rosette using an acidwashed (Suprapur MERCK HCl) Teflon tube inside a clean room. The rest of the procedure (gas injection and incubation) was identical to the one described above for routine sampling. For each depth and each condition, the incubations were performed in triplicates. The mean rates of nitrogen fixation have been compared for each depth and each condition using a student test $(\alpha=0.01)$.

\subsection{Cyanobacterial Diazotroph Concentrations}

[11] At five selected long stations (stations 2, 10, 18, 27, and 29), the concentration of unicellular cyanobacterial diazotrophs belonging to different size classes were assessed at 5-m depth. Filamentous species were enumerated at the same stations plus two additional stations (stations 22 and 25).

\subsubsection{Tyramide Signal Amplification-Fluorescent in Situ Hybridization}

[12] Before hybridization, water samples were sizefractionated: 4.5-L samples were gravity-filtered through $10-\mu \mathrm{m}$ ISOPORE ${ }^{\mathrm{TM}} 47-\mathrm{mm}$ filters. Two liters of the filtrate were then collected by gravity on $3-\mu \mathrm{m}$ ISOPORE ${ }^{\mathrm{TM}} 47-\mathrm{mm}$ filters, and finally, $200 \mathrm{~mL}$ of the filtrate were collected under $200-\mathrm{mm} \mathrm{Hg}$ vacuum on $0.2-\mu \mathrm{m}$ ISOPORE $^{\mathrm{TM}} 47-\mathrm{mm}$ filters. Once collected, cells affixed to the filters were fixed with $1 \%$ paraformaldehyde $(\mathrm{pH} 7.2$, buffered with PBS and clarified by filtration, Sigma-Aldrich) at room temperature for $15 \mathrm{~min}$. Cells were subsequently dehydrated with $5 \mathrm{~mL}$ of $100 \%$ ethanol molecular grade at room temperature for $10 \mathrm{~min}$ and stored at $-80^{\circ} \mathrm{C}$.

[13] Hybridizations were done according to Biegala et al. [2002] with slight modifications [Biegala and Raimbault, 2008]. In brief, 16S rRNA were hybridized with horseradish peroxidase (HRP) labeled Nitro821 probe (CAA GCC ACA CCT AGT TTC, Thermo Electron Corporation, Ulm, Germany) specific for diazotrophic unicellular cyanobacteria [Mazard et al., 2004]. The hybridized cells were then stained with a green fluorescent dye (fluorescein isothiocyannate (FITC)) using the tyramide signal amplification system (TSA kit, PerkinElmer). Prokaryotic and eukaryotic DNA was then counterstained with a blue fluorescent dye (4',6' Di Amidino-2-Phényl Indole (DAPI), Sigma-Aldrich).

\subsubsection{Cell Counts and Microscopy}

[14] For unicellular diazotrophic cyanobacteria, the entire surface of each filter portion was counted, which corresponded to 20 to 25 microscopic fields. Cells less than $3 \mu \mathrm{m}$ in size attached to particles or on larger algae were scored as picoplankton. For all three size fractions, diazotrophs were counted with an epifluorescence BX61 microscope 

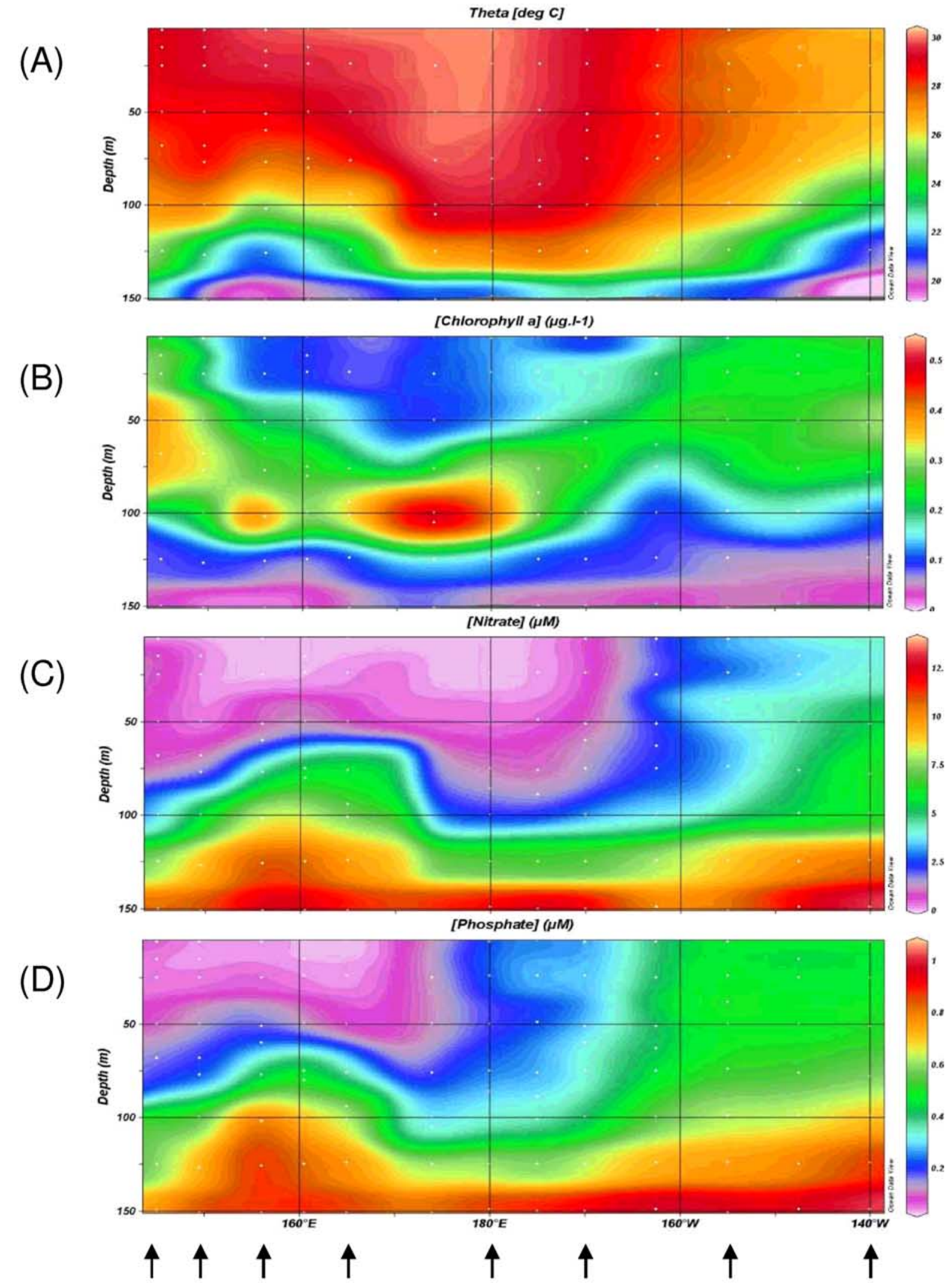

St.27St.25St.22St.18 St.14 St.10 St.6 St.2

Figure 2 
Table 1. Water Column Parameters Measured at Coastal Stations 29 and $30^{\mathrm{a}}$

\begin{tabular}{|c|c|c|c|c|c|c|c|}
\hline & $\begin{array}{c}\text { Temperature } \\
\left({ }^{\circ} \mathrm{C}\right)\end{array}$ & $\begin{array}{c}{[\mathrm{Chl} \mathrm{a}]} \\
\left(\mathrm{mg} \mathrm{m}^{-3}\right)\end{array}$ & $\begin{array}{c}{[\text { Nitrate }]} \\
\left(\mu \mathrm{mol} \mathrm{L}^{-1}\right)\end{array}$ & $\begin{array}{l}{[\text { Phosphate }]} \\
\left.(\mu \mathrm{mol} \mathrm{L})^{-1}\right)\end{array}$ & $\begin{array}{c}\mathrm{N}_{2} \text { Fixation Total } \\
\left(\mathrm{nmol} \mathrm{L} \mathrm{L}^{-1} \mathrm{~d}^{-1}\right)\end{array}$ & $\begin{array}{c}\mathrm{N}_{2} \text { Fixation }>10 \mu \mathrm{m} \\
\left(\mathrm{nmol} \mathrm{L}{ }^{-1} \mathrm{~d}^{-1}\right)\end{array}$ & $\begin{array}{c}\mathrm{N}_{2} \text { Fixation }<10 \mu \mathrm{m} \\
\left(\text { nmol L } \mathrm{L}^{-1} \mathrm{~d}^{-1}\right)\end{array}$ \\
\hline Station $29(5 \mathrm{~m})$ & 27.5 & 0.14 & $<\mathrm{DL}$ & 0.15 & 38 & 12.8 & 34.3 \\
\hline Station $30(5 \mathrm{~m})$ & 27.5 & 0.14 & $<\mathrm{DL}$ & 0.13 & 269 & 80.9 & 85 \\
\hline Station $30(30 \mathrm{~m})$ & 27.3 & 0.18 & 0.05 & 0.14 & 610 & 31.8 & 545 \\
\hline Station $30(60 \mathrm{~m})$ & 27.3 & 0.38 & 0.10 & 0.15 & 101 & 10.4 & 110 \\
\hline Station $30(100 \mathrm{~m})$ & 26.4 & 0.08 & 0.68 & 0.30 & 36.6 & 6.6 & 13.6 \\
\hline
\end{tabular}

${ }^{\mathrm{a}}$ Coordinates are as follows: station $29,-4.8^{\circ} \mathrm{S}$ to $145^{\circ} \mathrm{W}$; station $30,-5.8^{\circ} \mathrm{S}$ to $147^{\circ} \mathrm{W}$.

(Olympus Optical Company Limited). The microscope was equipped with a mercury lamp (HBO 100W/2, Osram, Germany), a $10 \times$ objective (NA $0.3 \mathrm{~N}$ Plan Fluor DT: $10 \mathrm{~mm}$, Olympus), a $40 \times$ objective (NA $0.75 \mathrm{~N}$ Plan Fluor PH2 DT: $0.51 \mathrm{~mm}$, Olympus), and a digital camera (Coolpix 5400, Nikon, Japan). The excitation (ex.) and emission (em.) dichroïc filters used were as follows: $360 \pm 20$ ex., $410 \pm 5 \mathrm{em}$. for DAPI (blue fluorescence) and $480 \pm 20 \mathrm{ex}$, $535 \pm 40 \mathrm{em}$. for FITC (green fluorescence). Every unicellular diazotrophic cyanobacteria from all three size fractions was counted using the $40 \times$ objective, and a second count was done using the $10 \times$ objective on the $3-10 \mu \mathrm{m}$ and $>10-\mu \mathrm{m}$ size fractions to determine the abundances of nanoplanktonic unicellular diazotrophs only. For 3-10 $\mu \mathrm{m}$ and $>10-\mu \mathrm{m}$ size fractions, picoplanktonic cells counts were obtained by subtracting nanoplanktonic counts from total counts.

[15] Concentration of Trichodesmium spp. was determined by filtering $250 \mathrm{~mL}$ of seawater onto $8-\mu \mathrm{m}$ pore size, 25-mm-diameter Nucleopore filters. Filters were placed cell side up on a glass slide, and trichomes were enumerated by direct microscopic counts using a $20 \times$ magnification.

\section{Results}

\subsection{Environmental Conditions}

[16] Hydrographic and biogeochemical parameters measured at oceanic stations during the equatorial transect were representative of the two main subregions, as reported in the literature (see section 1). At the time of the cruise, $160^{\circ} \mathrm{W}$ corresponded to the transition zone between the upwellingaffected waters and the warm pool and was characterized by strong surface temperature, nutrients, and chlorophyll gradients (Figure 2). On the eastern side of the transect $\left(140^{\circ} \mathrm{W}\right.$ to $\left.160^{\circ} \mathrm{W}\right)$, nutrient and chlorophyll $a$ concentrations were consistent with HNLC conditions (Figure 2), with high surface nitrate and phosphate concentrations $(2-4 \mu \mathrm{mol}$ $\mathrm{L}^{-1}$ and $0.4-0.5 \mu \mathrm{mol} \mathrm{L}^{-1}$, respectively), relatively low dissolved iron (DFe) concentrations $\left(0.2 \mathrm{nmol} \mathrm{L}{ }^{-1}\right)$ (L. O. Slemons et al., manuscript in review, 2009), and chlorophyll $a$ concentrations of $0.2 \mathrm{mg} \mathrm{m}^{-3}$. Westward of $160^{\circ} \mathrm{W}$, surface nitrate and phosphate concentrations decreased progressively to reach 0.03 and $0.25 \mu \mathrm{mol} \mathrm{L}^{-1}$, respectively, around the International Date Line (station 14), the latter falling below $0.03 \mu \mathrm{mol} \mathrm{L}{ }^{-1}$ at $165^{\circ} \mathrm{E}$ (station 18). Nitrate concentrations remained below detection until the end of the equatorial transect $\left(145^{\circ} \mathrm{E}\right)$, but phosphate concentrations increased slightly to $0.08 \mu \mathrm{mol} \mathrm{L^{-1 }}$ at the last equatorial station $\left(145^{\circ} \mathrm{E}\right.$, station 27$)$. The two coastal stations 29 $\left(-4.8^{\circ} \mathrm{S}\right.$ to $\left.145^{\circ} \mathrm{W}\right)$ and $30\left(-5.8^{\circ} \mathrm{S}\right.$ to $\left.147^{\circ} \mathrm{W}\right)$ exhibited surface nitrate concentrations below detection limit and

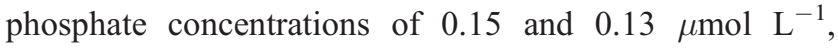
respectively (data are presented separately in Table 1).

[17] Surface chlorophyll a concentrations decreased in the warm pool to reach $0.05 \mathrm{mg} \mathrm{m}^{-3}$ at $165^{\circ} \mathrm{E}$ (station 18 ), but were again elevated at the end of the transect and reached $0.26 \mathrm{mg} \mathrm{m}^{-3}$ at $145^{\circ} \mathrm{E}$ in the Bismarck Sea (station 27) and $0.14 \mathrm{mg} \mathrm{m}^{-3}$ at the two coastal stations 29 and 30 in surface (Table 1).

\subsection{Nitrogen Fixation Rates: "Bulk" Versus "Size Fractionation"}

[18] Nitrogen fixation rates exhibited strong zonal gradients (Figure 3): the lowest rates were measured in the HNLC waters, ranging from $0.06( \pm 0.02)$ to $2.8( \pm 2.1) \mathrm{nmol}$ $\mathrm{L}^{-1} \mathrm{~d}^{-1}$. They increased gradually toward the west, to reach an initial maximum centered on the International Date Line (stations 12, 14, and 16), with rates reaching $4.1( \pm 2.8)$ nmol L $\mathrm{L}^{-1} \mathrm{~d}^{-1}$ near the surface. A second maximum was reached west of the equatorial transect (stations 25 and 27), where the rates reached up to $18.2( \pm 2.8) \mathrm{nmol} \mathrm{L}^{-1} \mathrm{~d}^{-1}$ between 0 and 30-m depth. Finally, extremely high rates were measured at coastal stations close to Papua New Guinea, where they were twice the maximal surface rates measured at oceanic stations at station $29(38 \pm 9 \mathrm{nmol} \mathrm{N}$ $\left.\mathrm{L}^{-1} \mathrm{~d}^{-1}\right)$ and up to 34 times higher $\left(610 \pm 46 \mathrm{nmol} \mathrm{L} \mathrm{L}^{-1}\right.$ $\mathrm{d}^{-1}$ ) at station 30 at $30-\mathrm{m}$ depth (Table 1 ).

[19] Along the transect, maximal nitrogen fixation rates were observed at $50 \%$ of surface irradiance ( $\sim 5-\mathrm{m}$ depth) (Figure 3). However, at stations 2 and 30, the maximal rates were observed at 0.1 and $10 \%$ of surface irradiance, corresponding to $100-\mathrm{m}$ depth and $30-\mathrm{m}$ depth, respectively. Most of the oceanic nitrogen fixation was associated with the small size fraction (fraction $<10 \mu \mathrm{m}$ ), which accounted for $74 \%$ of total nitrogen fixation over oceanic stations (and $83 \%$ if we include the coastal stations). This size fraction dominated nitrogen fixation rates over most of the zonal

Figure 2. Vertical distributions $(0-150 \mathrm{~m})$ of (a) temperature, (b) chlorophyll $a$ concentrations $\left(\mu \mathrm{g} \mathrm{L}{ }^{-1}\right)$, (c) nitrate $(\mu \mathrm{mol}$ $\left.\mathrm{L}^{-1}\right)$, and (d) phosphate $\left(\mu \mathrm{mol} \mathrm{L}{ }^{-1}\right.$ ) over the equatorial transect (do not include coastal stations 29 and 30, given in Table 1). Long stations are indicated by black arrows in the bottom of the longitudinal sections. 
(A)

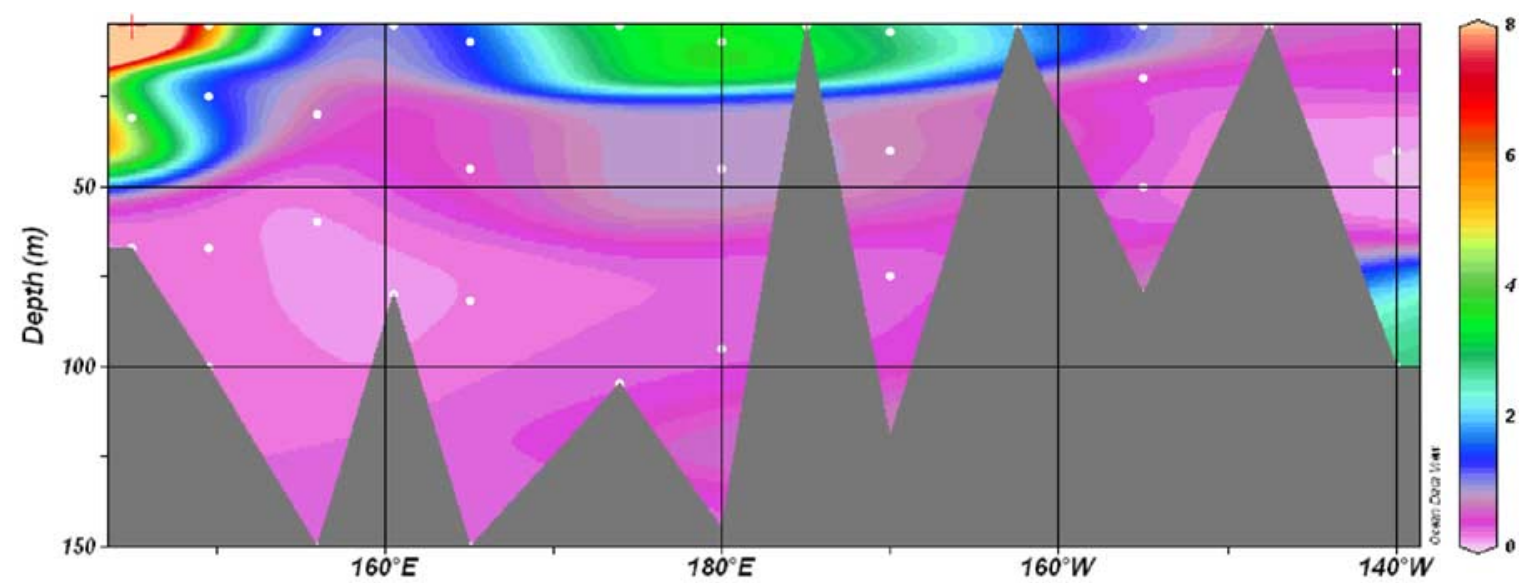

(B)

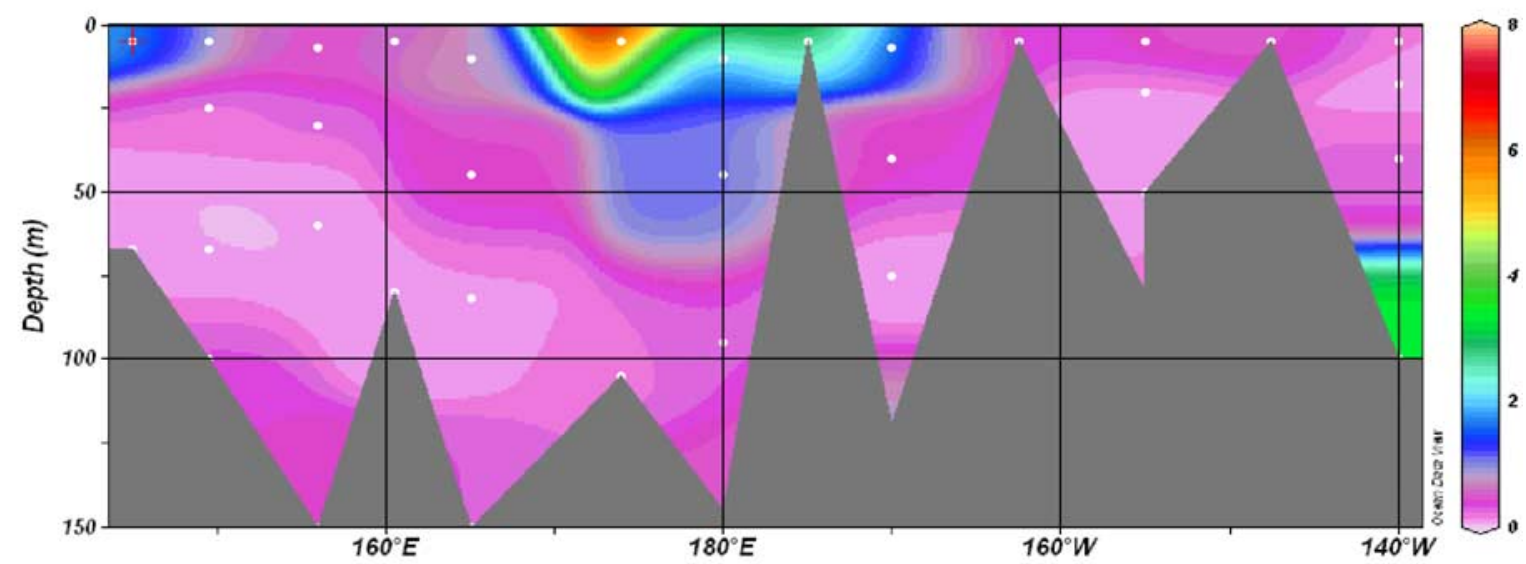

(C)

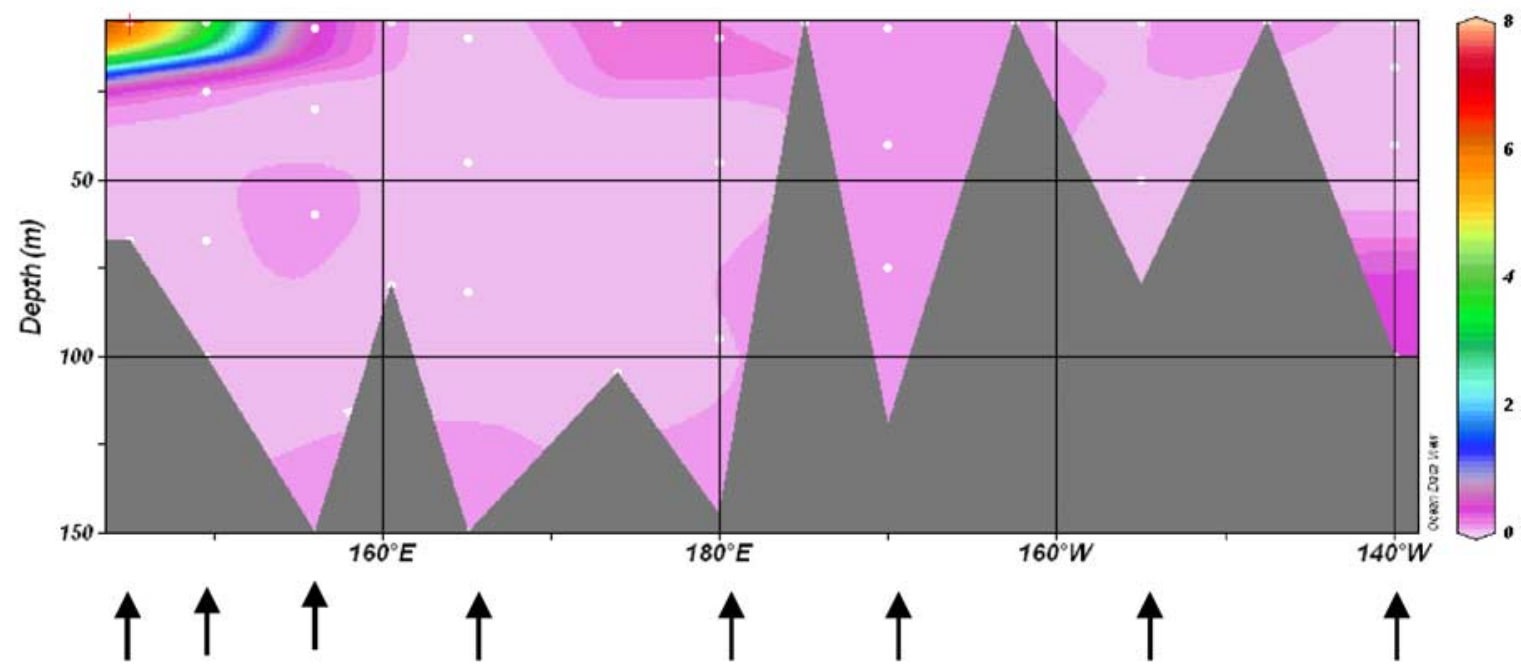

\section{St.27St.25 St.22 St.18 St.14 St.10 St.6 St.2}

Figure 3. Vertical distributions of nitrogen fixation rates $\left(\mathrm{nmol} \mathrm{N} \mathrm{L}^{-1} \mathrm{~d}^{-1}\right)$ over the equatorial transect. (a) Total fraction, (b) fraction $<10 \mu \mathrm{m}$, (c) fraction $>10 \mu \mathrm{m}$. Note that no data were available for the fractions $<10 \mu \mathrm{m}$ and $>10 \mu \mathrm{m}$ at station 27 (30-m-depth), explaining the different shape of the profiles at this station between Figures $3 \mathrm{a}, 3 \mathrm{~b}$, and $3 \mathrm{c}$. No interpolation has been performed when the full vertical profile was not available at "short stations" (gray areas) (do not include coastal stations 29 and 30, given in Table 1). Long stations are indicated by black arrows in the bottom of the longitudinal sections. 
(A)

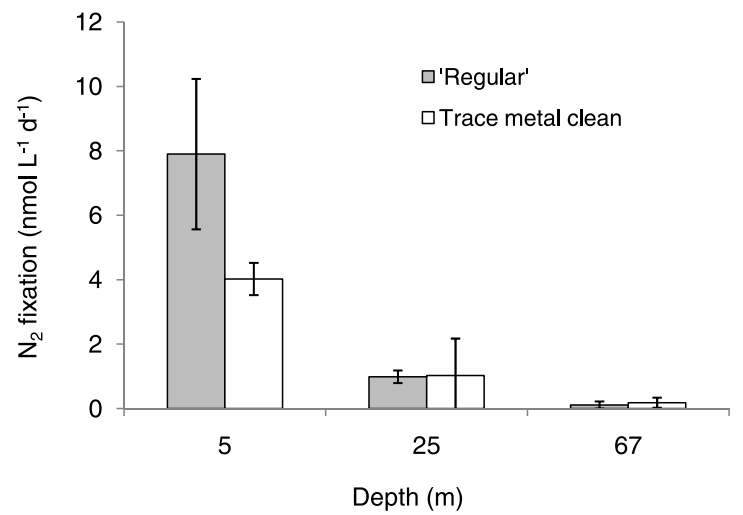

(B)

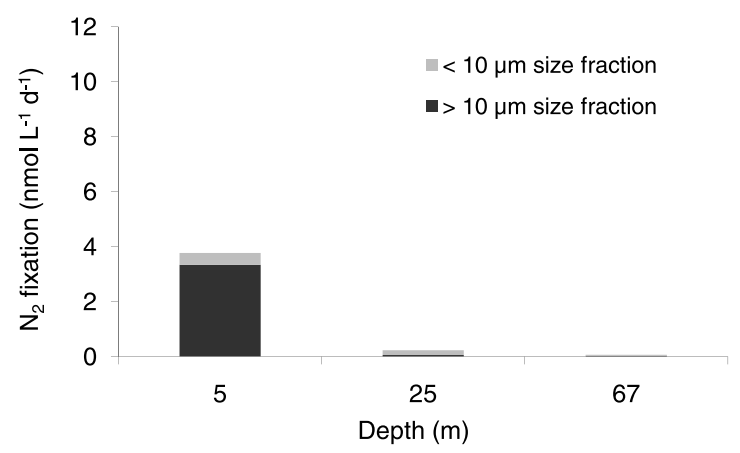

Figure 4. (a) Nitrogen fixation rates measured at station 25 at three depths, using both trace metal clean conditions (white bars) and non-trace-metal clean ("regular") conditions (gray bars). The error bars represent the standard deviation on the triplicate measurements. (b) Nitrogen fixation attributed to the $>10-\mu \mathrm{m}$ fraction (dark gray) and the $<10-\mu \mathrm{m}$ fraction (light gray). The size fractionation had been performed under trace metal clean conditions.

transect from stations 2 to 22 , whereas the large size fraction $(>10 \mu \mathrm{m})$ dominated at the two most western oceanic stations (stations 25 and 27). The extremely high rates reached measured at station 30 at $30-\mathrm{m}$ depth were largely attributable $(90 \%)$ to the $<10-\mu \mathrm{m}$ fraction (Table 1 ).

\subsection{Trace Metal Clean Versus Non-Trace-Metal Clean Profile}

[20] The vertical profile of nitrogen fixation performed at station 25 under trace metal clean versus "regular" conditions exhibited strong differences in nitrogen fixation rates (Figure 4). At the surface (5-m depth), the nitrogen fixation rates measured under trace metal clean conditions were 2 times lower than those measured under "regular" conditions; these differences were statistically different (triplicates, $p<0.01)$. At depths $(25-\mathrm{m}$ and $67-\mathrm{m}$ depth) where the nitrogen fixation rates were 4 to 8 times lower, there was no statistical difference between the rates measured under trace metal clean and "regular" conditions.

\subsection{Cyanobacterial Diazotroph Concentrations}

[21] On the basis of Tyramide Signal AmplificationFluorescent in Situ Hybridization (TSA-FISH) data and filamentous cyanobacteria counts at 5-m depth, our results suggest that unicellular diazotrophic cyanobacteria were present at all the stations tested along the zonal transect, while filamentous cyanobacteria were detected only close to Papua New Guinea (stations 22 to 29; Figure 6). Among them, only Trichodesmium has been observed, mainly the species Trichodesmium contortum and Trichodesmium tenue, the latter forming tuffs in surface waters (Figures $5 \mathrm{~g}$ and 5h). No Richelia has been observed in our samples. The density of unicellular cyanobacterial diazotrophs was dominated $(98 \%)$ by picoplanktonic cells, which were in low concentration ( 2 to 3 cell $\mathrm{mL}^{-1}$ ) at HLNC stations and 5 times more concentrated ( 10 to 17 cells $\mathrm{mL}^{-1}$ ) in the warm pool (Figure 6). These diazotrophic picocyanobacteria were detected in all three size fractions $(0.2-3 \mu \mathrm{m} ; 3-$ $10 \mu \mathrm{m}$; and $>10 \mu \mathrm{m}$ ), either as free-living organisms (data not shown) or associated with inert particles or eukaryotes (Figures $5 \mathrm{a}$ and $5 \mathrm{c}-5 \mathrm{f}$ ). Similarly, the nanocyanobacterial diazotrophs (which accounted for only $2 \%$ of the unicellular fraction with 0.18 to 0.54 cell $\mathrm{mL}^{-1}$ ) were either observed as free-living cells (data not shown) or in large aggregates within mucilage (Figure 5b). These nanoplanktonic cyanobacteria were recovered mainly in coastal and near-coastal stations, where Trichodesmium spp. was also observed at concentrations ranging from 0.02 to 1.85 trichome $\mathrm{mL}^{-1}$ (Figure 6).

\section{Discussion}

\subsection{Methodological Considerations}

[22] Comparison of the two vertical profiles taken at station 25 under trace metal clean and "regular" (nontrace-metal clean) conditions reveals that trace-metal-free conditions result in lower rates of ${ }^{15} \mathrm{~N}_{2}$ fixation at least in surface samples (Figure 4). These results are based on only one test station and thus should be viewed cautiously. The discrepancy might be due to an unintended fertilization by trace nutrients in the "regular" samples, such as iron, which is known to enhance diazotrophic growth and nitrogen fixation rates of Trichodesmium [e.g., Berman Frank et al., 2007]. We suggest this since, in the case of Trichodesmium, its cellular iron requirements are 7-11 times higher than those of eukaryotic phytoplankton strictly assimilating ammonium [Kustka et al., 2003]. However, the much higher rates under "regular" conditions were not seen at 25-m and 67-m depth, where both methods gave equivalent and much lower values. Parallel size fractionation was performed at these three depths and revealed a huge dominance of the large size fraction at 5 -m-depth $(89 \%$ of the total rates measured, including the presence of Trichodesmium spp., Figure $4 \mathrm{~b}$ ) and a dominance of the small size fraction at $25-\mathrm{m}$ and $67-\mathrm{m}$-depth ( $65 \%$ of total $\mathrm{N}_{2}$ fixation, Figure $\left.4 \mathrm{~b}\right)$. Different diazotroph communities may thus react in different ways to trace nutrient fertilization.

\subsection{Nitrogen Fixation Rates}

[23] This study provides the first data for nitrogen fixation in equatorial Pacific surface waters and is consistent with previous geochemical studies which suggested the occurrence of diazotrophy in this area [Yoshikawa et al., 2005]. 

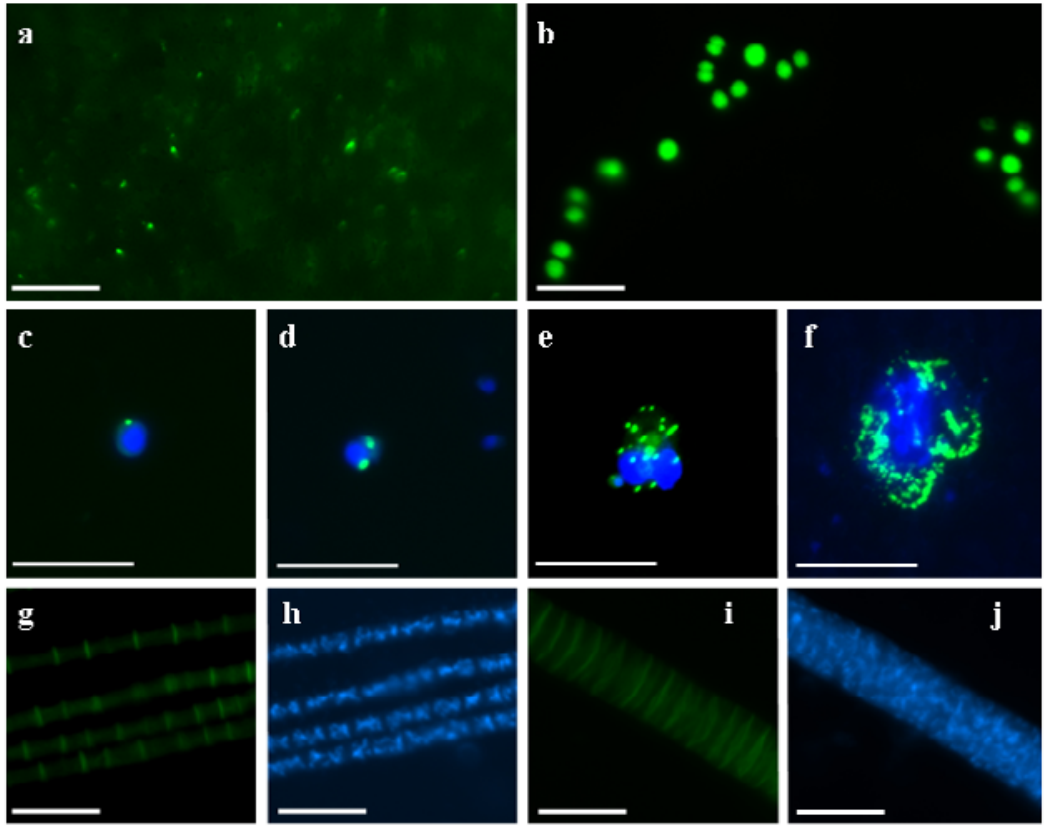

Figure 5. Epifluorescence micrographs from unicellular diazotrophic cyanobacteria. (a-f) Unicellular diazotrophic cyanobacteria cells hybridized with the specific Nitro821 probe, labeled with FITC (green). The labeled cells were of either (Figure 5a) picoplanktonic size associated on a large particle, (Figure 5b) nanoplanktonic size grouped together on a mucilage, or (Figures $5 \mathrm{c}-5 \mathrm{f}$ ) picoplanktonic size associated in different concentrations with larger eukaryotes. $(\mathrm{g}-\mathrm{j})$ Two filamentous cyanobacteria not labeled by Nitro821 probe (Figures 5g and 5h: Trichodesmium tenue-like; Figures 5i and 5j: Trichodesmium contortum-like). In blue are eukaryotic and prokaryotic DNA labeled by specific dye 4',6' Di Amidino-2Phényl Indole (DAPI). Bars, $20 \mu \mathrm{m}$.

Nitrogen fixation was indeed detected all along the transect, with rates ranging from $0.06( \pm 0.02)$ to $18.2( \pm 2.8) \mathrm{nmol}$ $\mathrm{L}^{-1} \mathrm{~d}^{-1}$, the maximum rates being reached in the oligotrophic warm pool. These rates are in the same order of magnitude as those measured in the tropical North Pacific, where nitrogen fixation is recognized to fuel a large part of new primary production [e.g., Karl et al., 1997]. However, the extremely high rates measured in coastal waters above the chlorophyll maximum $\left(610 \pm 46 \mathrm{nmol} \mathrm{L}{ }^{-1} \mathrm{~d}^{-1}\right)$ are to our knowledge among the highest yet measured in natural marine samples along with those detected by Montoya et al. [2004] in the Arafura Sea, south of Papua New Guinea (62 nmol $\mathrm{N} \mathrm{L}^{-1} \mathrm{~h}^{-1}$ over a $7 \mathrm{~h}$-incubation), and in the Mediterranean Sea (130-200 nmol L ${ }^{-1} \mathrm{~d}^{-1}$ [Rees et al., 2006]. The reasons for such high rates around Papua New Guinea remain unidentified.

[24] One of the most interesting features in this area is the clear dominance of nitrogen fixation associated with the $<10-\mu$ m fraction, which accounted for $74 \%$ of the total nitrogen fixation over oceanic stations (and for $83 \%$ if we include the coastal stations). The remaining percentage was attributed to the fraction $>10 \mu \mathrm{m}$. Despite the predominance of Trichodesmium in this latter fraction, the TSA-FISH data indicated that $10 \%$ of the picocyanodiazotrophs and nanocyanodiazotrophs were recovered in the microplanktonic fraction (in association with eukaryotes or inert microparticles). Consequently, the nitrogen fixation rates measured in the large size fraction are probably overestimated, and a portion may be associated with the picocyanodiazotrophs, reinforcing their biogeochemical importance in this environment. However, it is currently impossible to determine the components of nitrogen fixation attributable to Trichodesmium and to the picodiazotrophs associated with microparticles. The average surface rates attributed to the $<10-\mu \mathrm{m}$

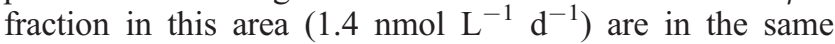
order of magnitude of those reported in the southwest Pacific by Garcia et al. [2007], but higher compared to those previously reported in tropical and subtropical regions, where typical values are less than $0.60 \mathrm{nmol} \mathrm{L}^{-1}$ $\mathrm{d}^{-1}$ (e.g., $0.38 \mathrm{nmol} \mathrm{L}{ }^{-1} \mathrm{~d}^{-1}$ [Zehr et al., 2001]; 0.16 to $0.55 \mathrm{nmol} \mathrm{L}{ }^{-1} \mathrm{~d}^{-1}$ [Dore et al., 2002]; $0.48 \mathrm{nmol} \mathrm{L}{ }^{-1} \mathrm{~d}^{-1}$ [Falcon et al., 2004]). This result is consistent with the emergent recognition that unicellular nitrogen-fixing organisms can make a larger contribution to marine nitrogen fixers than previously thought [Zehr et al., 2001; Montoya et al., 2004], which appears to be particularly true in the tropical Pacific [Church et al., 2008].

\subsection{Diazotrophic Cyanobacteria}

[25] Growing evidence indicates that unicellular photosynthetic diazotrophs play a significant role in the marine nitrogen budget. Interestingly, the abundance of unicellular diazotroph community on this cruise was clearly dominated by the picoplanktonic $(<3 \mu \mathrm{m})$ fraction, which represented $98 \%$ of the community (Figures 5 and 6 ). These picodiazo- 


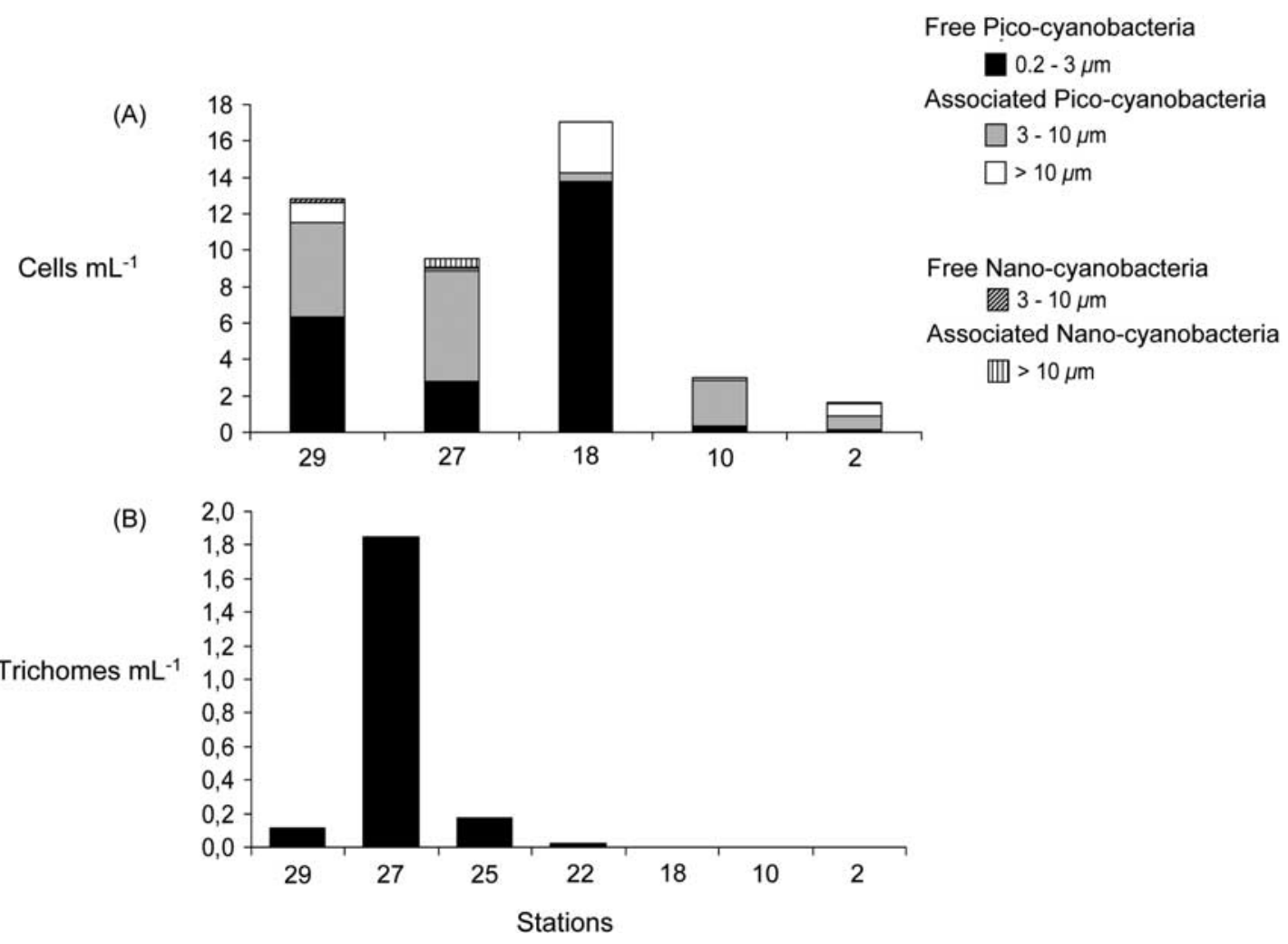

Figure 6. (a) Cell concentrations of Nitro821-targeted unicellular diazotrophs from picoplanktonic and nanoplanktonic sizes. Counts of free-living or particulate-associated cells were recovered from three size fractions $(0.2-3 \mu \mathrm{m}, 3-10 \mu \mathrm{m}$, and $>10 \mu \mathrm{m})$. (b) Trichome concentrations.

trophs are possibly related to the uncultivated group A [e.g., Zehr et al., 2008; Mazard et al., 2004; Biegala and Raimbault, 2008], a widely distributed phylotype [Church et al., 2008]. This is the first time that such a large contribution of picocyanodiazotrophs $(0.7$ to $1.5 \mu \mathrm{m})$ has been shown in oceanic waters. However, similar patterns have recently been reported in coastal waters of New Caledonia and northwestern Mediterranean Sea, where picocyanobacterial diazotroph dominated the community of unicellular diazotrophs at $97 \%$ in austral spring and at 99.9\% all along the year [Biegala and Raimbault, 2008; Le Moal and Biegala, 2009].

[26] Over the equatorial transect, the concentrations of diazotrophic picocyanobacteria and nanocyanobacteria were either equal or less abundant than what has been previously reported in the Pacific [Campbell et al., 2005; Church et al., 2008; Biegala and Raimbault, 2008; Bonnet et al., 2008]. However, our molecular study is based on five stations, and we strongly suspect higher unicellular diazotrophs densities at the stations exhibiting the highest $\mathrm{N}_{2}$ fixation rates in the $<10-\mu \mathrm{m}$ size fraction (stations 12, 14, and 16), where no FISH data are available. The $\mathrm{N}_{2}$ fixation rates per cell vary between 0.04 and 0.2 pmol cell $\mathrm{L}^{-1} \mathrm{~d}^{-1}$, which is within the range reported in the literature [e.g., Falcon et al., 2005]. However, we cannot exclude the contribution of bacterial phylotypes (not detected here) to the $\mathrm{N}_{2}$ fixation fluxes. The diazotrophic picocyanobacteria were present either as freeliving organisms recovered in the $0.2-3-\mu \mathrm{m}$ size fraction or associated to inert particles or intracellular of eukaryotes within the $3-10-\mu \mathrm{m}$ and $>10-\mu \mathrm{m}$ size fractions (Figures $5 \mathrm{a}$, $5 c-5 f$, and 6). Similar results were observed in the coastal waters of the southwest Pacific, where diazotrophic picocyanobacteria were suspected to be cyanobionts of heterotrophic dinoflagellates [Biegala and Raimbault, 2008]. However, Crocosphaera-like cells from this study were either free-living or associated with mucilage rather than particles, and these cells were not observed as intracellular symbionts of eukaryotes (Figure $5 \mathrm{~b}$ ). The presence of diazotrophic nanoplanktonic cyanobionts has nonetheless been described in the tropical unthecated dinoflagellate Histoneis spp. [Foster et al., 2006]. Eukaryotes are known for being able to develop symbiosis with either heterotrophic or photosynthetic prokaryotes, such as alpha proteobacteria and cyanobacteria [Dyall et al., 2004]. Similar fluorescent labeling of prokaryotic symbionts has already been described within unthecated dinoflagellates (Gyrodinium instriatum) [Alverca et al., 2002]. These authors have shown that numerous dividing proteobacteria were located both within the cytoplasm and the nucleus among condensed chromosomes. Such intimate relationship between prokaryotes and eukaryotes seems very common among oceanic eukaryotic cells [e.g., Biegala et al., 2005], and host organisms may benefit from the additional source of carbon and nitrogen provided by potentially diazotrophic picocyanobacteria. The cyanobionts may in turn be sheltered in 
micronutrient rich environment. Although symbioses are suspected in this study, recent predation cannot be excluded.

[27] The large size fraction $(>10 \mu \mathrm{m})$ accounted for $26 \%$ of total nitrogen fixation over the transect $(17 \%$ if we include coastal stations). Among this fraction, Trichodesmium reached highest densities ( 1.85 trichome $\mathrm{mL}^{-1}$ ) close to the coast of Papua New Guinea, which is consistent with previous studies that reported its presence in the western tropical Pacific [Neveux et al., 2006; Moutin et al., 2005; Campbell et al., 2005; Dupouy et al., 2000].

\subsection{Spatial Distribution of $\mathbf{N}_{2}$ Fixation Rates and Community Changes in Relation With Environmental Parameters}

\subsubsection{HNLC Waters}

[28] The very low $\mathrm{N}_{2}$ fixation rates and scarcity of diazotroph organisms in the surface HNLC waters are probably best explained by the presence of the active equatorial upwelling in this area, which provides nutrients from deep waters [e.g., Carr et al., 1995]. Consequently, surface nitrate concentrations on our cruise reached values as high as $4 \mu \mathrm{mol} \mathrm{L}^{-1}$ (Figure 2). In these nitrogen-replete waters, diazotrophs are likely outcompeted by nondiazotrophic phytoplankton, such as picophytoeukaryotes, dinoflagellates, and diatoms, which are more competitive than diazotrophs in high-nitrate conditions and make a large contribution to the total primary productivity [e.g., Chavez et al., 1990]. The upwelling was associated with colder waters $\left(26.4^{\circ} \mathrm{C}\right.$ ) compared to the warm pool (up to $30.4^{\circ} \mathrm{C}$; Figure 2). $\mathrm{N}_{2}$ fixation is known to be a temperaturedependent process [e.g., Staal et al., 2003], but the water masses studied were in the appropriated range for $\mathrm{N}_{2}$ fixation to occur $\left(24-30^{\circ} \mathrm{C}\right)$ [Breitbarth et al., 2007]. Consequently, temperature is probably not the main factor explaining the scarcity of $\mathrm{N}_{2}$ fixers in HNLC waters.

[29] Although nitrogen fixation rates were very low in surface HNLC waters, measurable and significant activity $\left(2.8 \pm 2.1 \mathrm{nmol} \mathrm{N} \mathrm{L}{ }^{-1} \mathrm{~d}^{-1}\right)$ was detected within the small size fraction in deeper waters (100 $\mathrm{m}$, station 2$)$, where nitrate concentrations reached $6.5 \mu \mathrm{mol} \mathrm{L}{ }^{-1}$. It has to be noted that these deep values might have been overestimated due to the deck incubations performed at surface temperature $\left(26.3^{\circ} \mathrm{C}\right)$ and not at $100-\mathrm{m}$ temperature $\left(21.5^{\circ} \mathrm{C}\right)$. However, relatively few studies have considered the influence of combined nitrogen on planktonic marine nitrogen fixation, but recently, Holl and Montoya [2005] have shown in continuous cultures of diazotrophs that such DIN concentrations can inhibit partially nitrogen fixation, and 30\% of nitrogenase activity was occurring simultaneously as nitrate uptake. Our understanding of marine nitrogen fixation is constantly evolving, and emerging satellite [Westberry et al., 2005], geochemical [Deutsch et al., 2001, 2007], and biological [Needoba et al., 2007] evidence suggests that diazotrophy may not be limited to the nitrate-depleted surface waters of the oligotrophic ocean.

\subsubsection{Warm Pool and Coastal Waters}

[30] $\mathrm{N}_{2}$ fixation rates exhibited higher rates in the warm pool compared to HNLC waters and reached extremely high values in the western part of the equatorial section. Contrary to the unicellular organisms, which were present all along the transect, Trichodesmium was restricted to the warm pool, especially close to the coast of Papua New Guinea. This type of geographical segregation has already been shown by Campbell et al. [2005] south of this region and by Montoya et al. [2007] in the North Atlantic. Recent molecular work using qPCR of nifH also indicates that there may be interbasin differences in the relative importance of diazotrophic assemblages, with Trichodesmium being of greater quantitative significance in the North Atlantic [Langlois et al., 2008], while coccoids are more dominant through large stretches of the North Pacific [Church et al., 2005, 2008]. The high iron-rich dust deposition in the Atlantic compared to the Pacific Ocean [Jickells et al., 2005] cannot be excluded to explain such interbasin trends in diazotroph population composition; however, the ecological factors that control marine nitrogen fixation in the ocean are not fully resolved [Carpenter and Capone, 2008]. This is particularly the case for the unicellular diazotrophs, mainly the picocyanodiazotrophs that have not been brought into culture yet and for which there are very few physiological data available.

[31] The oceanic distribution of Trichodesmium is known to be well-constrained by seawater temperature $\left(20-30^{\circ} \mathrm{C}\right)$ [Capone et al., 1997]. Recently, Breitbarth et al. [2007] have shown in culture that maximal growth and $\mathrm{N}_{2}$ fixation rates were occurring at $24-30^{\circ} \mathrm{C}$. Sea surface temperature did not vary substantially over the warm pool between the stations revealing the presence or the absence of Trichodesmium (28.5 to $30.3^{\circ} \mathrm{C}$, Figure 2), indicating that surface temperature could probably not explain the patchiness in Trichodesmium distribution.

[32] However, it is interesting to note that Trichodesmium were present in the surface waters exhibiting the highest mixed layer DFe concentrations close to the coast of Papua New Guinea ( $0.9 \mathrm{nmol} \mathrm{L}{ }^{-1}$ at $\left.145^{\circ} \mathrm{E}\right)$ (L. O. Slemons et al., manuscript in review, 2009). The Papua New Guinea plateau is known to be a source of iron for adjacent waters, as well as for the Equatorial Undercurrent [Mackey et al., 2002]. The same pattern was described by Campbell et al. [2005]. Among the ecological factors that have been seen to control diazotrophs growth and nitrogen fixation, iron plays a central role [e.g., Kustka et al., 2003]. However, unicellular and colonial diazotrophs exhibit different strategies to balance iron demand. Berman-Frank et al. [2007] determined that the Fe:C ratio of Trichodesmium are up to 100 times higher than those of unicellular diazotrophs such as Cyanothece. This could explain why Trichodesmium blooms are most often observed in coastal areas [e.g., Carpenter and Capone, 1992] proximal to iron inputs, compared to unicellular, which are present over a larger range of DFe concentrations.

[33] Phosphorus availability has also been shown to control oceanic nitrogen fixation [e.g., Sañudo-Wilhelmy et al., 2001; Moutin et al., 2005; Sohm et al., 2008]. Phosphate concentrations were high around the International Date Line $\left(0.25 \mu \mathrm{mol} \mathrm{L}{ }^{-1}\right.$, station 14), where we observed the first maximum of nitrogen fixation attributed to small diazotrophs. The phosphate concentrations then decreased in the middle of the warm pool to reach $0.03 \mu \mathrm{mol} \mathrm{L} \mathrm{L}^{-1}$ (stations 18, 19, and 20); these stations corresponded to 
the lowest nitrogen fixation rates measured, indicating a possible phosphate limitation in this area. In the western part of the warm pool and close to Papua New Guinea, phosphate concentrations increased up to $0.15 \mu \mathrm{mol} \mathrm{L}^{-1}$, possibly explaining the development of both unicellular and filamentous diazotrophs.

\subsection{Biogeochemical Implications}

[34] The areally integrated nitrogen fixation rates we report in the equatorial Pacific for the oceanic stations range from 18 to $358 \mu \mathrm{mol} \mathrm{N} \mathrm{m}{ }^{-2} \mathrm{~d}^{-1}$, the lowest rates being associated with HNLC waters, and the highest with western oceanic equatorial stations. In HNLC waters, we calculate that the input of "new" nitrogen due to nitrogen fixation represents only $2 \%$ of the upwelled nitrogen. This calculation was done considering a net supply of nitrate of $4.3 \mathrm{mmol} \mathrm{m} \mathrm{m}^{-2} \mathrm{~d}^{-1}$ [Carr et al., 1995]. On the basis of a $\mathrm{C}: \mathrm{N}=7$, the contribution of nitrogen fixation to the nitrogen demand of net primary productivity measured in the HNLC waters is only $0.8 \%$, indicating that primary production is mostly fueled by other forms of biologically available nitrogen, probably mostly nitrate advected into surface waters. In the warm pool, nitrogen fixation accounted on average for $22 \%$ of the nitrogen demand of net primary productivity. As nitrogen fixation represents a source of "new" nitrogen (as opposed to recycled nitrogen), it is perhaps more accurate to compare the $\mathrm{N}_{2}$ fixation rates with new production rather than net primary production. These data are not available for the cruise, but if we consider new primary production from Aufdenkampe et al. [2002] available for the central warm pool, the contribution of nitrogen fixation to new primary production is much higher and may reach $50 \%$ of the nitrogen demand in this area, which is consistent with previous studies in the open ocean [e.g., Karl et al., 1997]. Other sources of new nitrogen, such as nitrate, may come from vertical diffusion from depth, or from horizontal advection from the eastern equatorial $\mathrm{Pa}-$ cific [Peña et al., 1994; Yoshikawa et al., 2006].

\section{Conclusions}

[35] In summary, this study provides for the first time data on nitrogen fixation rates and diazotroph size class diversity in the equatorial Pacific. We show that trace metal clean conditions during ${ }^{15} \mathrm{~N}_{2}$ incubations may be necessary to avoid an overestimation of nitrogen fixation rates, at least in the $>10-\mu \mathrm{m}$ size fraction. These original data suggest the presence of active nitrogen-fixing organisms across the whole transect, with particular biogeochemical importance in the nitrate-depleted waters of the warm pool, where they account for up to $50 \%$ of the nitrogen demand of new primary production. Our data also reveal active nitrogen fixation associated with the small size fraction in deeper nitrate-rich waters, confirming the emerging recognition that marine nitrogen fixation is more widespread than previously thought and not totally restricted to the nitratedepleted surface oligotrophic ocean. In our study, nitrogen fixation rates attributed to the small size fraction accounted for more than $74 \%$ of the total rates over the whole transect, indicating that unicellular diazotrophs play a major role in this environment. Among the diazotrophic unicellular organisms, $98 \%$ of the total abundance were picocyanobacteria. This is the first report of the dominance of these organisms in oceanic waters. We found a clear longitudinal pattern of niche partitioning between diazotroph size classes. Unicellular diazotrophs were distributed all along the transect, whereas Trichodesmium was restricted to coastal and near-coastal stations. Dissolved iron and phosphorus conditions have been hypothesized to explain Trichodesmium distribution, but the ecological factors that control unicellular diazotrophs in the ocean still remain unclear. The isolation and characterization of the physiology of the recently discovered diazotrophic picocyanobacteria [Biegala and Raimbault, 2008; Zehr et al., 2008] would provide important information in interpreting their distributions in the field. It will also be useful to determine their contribution within each size fraction to overall nitrogen fixation.

[36] Acknowledgments. This work was performed within the framework of the NSF program EUC-Fe (http://www.ocean.washington.edu/ cruises/KiloMoana2006/index.html) and constitutes the French contribution (ISOFERIX project, LEFE-CYBER program). We warmly thank the principal investigator J. W. Murray, as well as the captain and crew of the R/V Kilo Moana for their cooperative work at sea. We also thank F. Lacan, C. Jeandel, and M. Souhaut for their collaborative work in Toulouse. Finally, we thank S. Pal and J. Kirkpatrick from the University of Washington for nutrient analyses and T. Gunderson from the University of Southern California for assistance with ${ }^{15} \mathrm{~N}$ tracer experiments.

\section{References}

Alverca, E., I. C. Biegala, G. M. Kennaway, J. Lewis, and S. Franca (2002), In situ identification and localization of bacteria associated with Gyrodinium instriatum (Gymnodiniales, Dinophyceae) by electron and confocal microscopy, Eur. J. Phycol., 37, 523-530, doi:10.1017/S0967026202003955.

Aufdenkampe, A. K., J. J. McCarthy, C. Navarette, M. Rodier, J. Dunne, and J. W. Murray (2002), Biogeochemical controls on new production in the tropical Pacific, Deep Sea Res., Part II, 49, 2619-2648, doi:10.1016/ S0967-0645(02)00051-6.

Berman-Frank, I., A. Quigg, Z. V. Finkel, A. J. Irwin, and L. Haramaty (2007), Nitrogen-fixation strategies and Fe requirements in cyanobacteria, Limnol. Oceanogr., 52, 2260-2269.

Biegala, I. C., and P. Raimbault (2008), High abundance of diazotrophic pico-cyanobacteria $(<3 \mu \mathrm{m})$ in a south-west Pacific coral lagoon, Aquat. Microb. Ecol., 51, 45-53, doi:10.3354/ame01185.

Biegala, I. C., G. Kennaway, J. F. Lennon, D. Vaulot, and N. Simon (2002), Identification of bacteria associated with dinoflagellates (Dinophyceae) Alexandrium spp. using TSA-FISH (Tyramide Signal AmplificationFluorescent In Situ Hybridization) and confocal microscopy, J. Phycol., 38, 404-411, doi:10.1046/j.1529-8817.2002.01045.x.

Biegala, I. C., M. Cuttle, I. Mary, and M. V. Zubkov (2005), Hybridization of picoeukaryotes by eubacterial probes is wide-spread and may introduce bias in biodiversity researches or reveal intimate relationship between both types of organisms, Aquat. Microb. Ecol., 41, 293-297, doi:10.3354/ame041293.

Bonnet, S., et al. (2008), Nutrient limitation of primary productivity in the southeast Pacific (BIOSOPE cruise), Biogeosciences, 5, 1-11.

Breitbarth, E., A. Oschlie, and J. LaRoche (2007), Physiological contrainsts on the global distribution of Trichodesmium: Effect of temperature on diazotrophy, Biogeosciences, 4, 53-61.

Campbell, L., E. J. Carpenter, J. P. Montoya, A. B. Kustka, and D. G. Capone (2005), Picoplankton community structure within and outside a Trichodesmium bloom in the southwestern Pacific Ocean, Vie Milieu, 55, $185-195$.

Capone, D. G., J. P. Zehr, H. W. Paerl, B. Bergman, and E. J. Carpenter (1997), Trichodesmium, a globally significant marine cyanobacterium, Science, 276, 1221-1229, doi:10.1126/science.276.5316.1221.

Capone, D. G., J. A. Burns, J. P. Montoya, A. Subramaniam, C. Mahaffey, T. Gunderson, A. F. Michaels, and E. J. Carpenter (2005), Nitrogen fixation by Trichodesmium spp.: An important source of new nitrogen to the tropical and subtropical North Atlantic Ocean, Global Biogeochem. Cycles, 19, GB2024, doi:10.1029/2004GB002331. 
Carpenter, E. J. (1983), Physiology and ecology of marine Oscillatoria (Trichodesmium), Mar. Biol. Lett., 4, 69-85.

Carpenter, E. J., and D. G. Capone (1992), Significance of Trichodesmium blooms in the marine nitrogen cycle, in Marine Pelagic Cyanobacteria: Trichodesmium and Other Diazotrophs, edited by E. J. Carpenter, D. G. Capone, and J. Rueter, pp. 211-217, Kluwer Acad., Dordrecht, Netherlands.

Carpenter, E. J., and D. G. Capone (2008), Nitrogen fixation in the marine environment, in Nitrogen in the Marine Environment, edited by D. G. Capone et al., pp. 141-198, Academic Press, San Diego, Calif.

Carr, M.-E., M. R. Lewis, and D. Kelley (1995), A physical estimate of new production in the equatorial Pacific along $150^{\circ} \mathrm{W}$, Limnol. Oceanogr., 40 , $138-147$

Chavez, F. P., and R. T. Barber (1987), An estimate of new production in the equatorial Pacific, Deep Sea Res., 34, 1229-1243, doi:10.1016/01980149(87)90073-2.

Chavez, F., K. R. Buck, and R. T. Barber (1990), Phytoplankton taxa in relation to primary production in the equatorial Pacific, Deep Sea Res., 37, 1733-1752, doi:10.1016/0198-0149(90)90074-6.

Church, M. J., B. D. Jenkins, D. M. Karl, and J. P. Zehr (2005), Vertical distributions of nitrogen-fixing phylotypes at Stn ALOHA in the oligotrophic North Pacific Ocean, Aquat. Microb. Ecol., 38, 3-14, doi:10.3354/ame038003.

Church, M. J., K. M. Björkman, D. M. Karl, M. A. Saito, and J. P. Zehr (2008), Regional distributions of nitrogen-fixing bacteria in the Pacific Ocean, Limnol. Oceanogr., 53, 63-77.

Cullen, J. J. (1995), Status of the iron hypothesis after the open-ocean enrichment experiment, Limnol. Oceanogr., 40, 1336-1343.

Deutsch, C., N. Gruber, R. Key, and J. L. Sarmiento (2001), Denitrification and $\mathrm{N}_{2}$ fixation in the Pacific Ocean, Global Biogeochem. Cycles, 15, 483-506, doi:10.1029/2000GB001291.

Deutsch, C., J. L. Sarmiento, D. M. Sigman, N. Gruber, and J. P. Dunne (2007), Spatial coupling of nitrogen inputs and losses in the ocean, Nature, 445, 163-167, doi:10.1038/nature05392.

Dore, J. E., J. R. Brum, L. M. Tupas, and D. M. Karl (2002), Seasonal and interannual variability in sources of nitrogen supporting export in the oligotrophic subtropical North Pacific Ocean, Limnol. Oceanogr., 47, $1595-1607$.

Dupouy, C., J. Neveux, A. Subramaniam, M. R. Mulholland, J. P. Montoya, L. Campbell, E. Carpenter, and D. G. Capone (2000), Satellite captures Trichodesmium blooms in the southwestern tropical Pacific, Eos Trans $A G U, 81,13$, doi:10.1029/00EO00008.

Dyall, S. D., M. T. Brown, and P. J. Johnson (2004), Ancient invasions: From endosymbionts to organelles, Science, 304, 253-257, doi:10.1126/ science. 1094884.

Falcon, L. I., E. J. Carpenter, F. Cipriano, B. Bergman, and D. G. Capone (2004), $\mathrm{N}_{2}$ fixation by unicellular bacterioplankton from the Atlantic and Pacific oceans: Phylogeny and in situ rates, Appl. Environ. Microbiol., 70, 765-770, doi:10.1128/AEM.70.2.765-770.2004

Falcon, L. I., S. Pluvinage, and E. J. Carpenter (2005), Growth kinetics of marine unicellular $\mathrm{N}_{2}$-fixing cyanobacterial isolates in continuous culture in relation to phosphorus and temperature, Mar. Ecol. Prog. Ser., 285, $3-$ 9, doi:10.3354/meps 285003

Foster, R. A., E. J. Carpenter, and B. Bergman (2006), Unicellular cyanobionts in open ocean dinoflagellates, radiolarians, and tintinnids: Ultrastructural characterization and immuno-localization of phycoerythrin and nitrogenase, J. Phycol., 42, 453-463, doi:10.1111/j.1529-8817.2006. 00206.x.

Garcia, N., P. Raimbault, and V. Sandroni (2007), Seasonal nitrogen fixation and primary production in the southwest Pacific: Nanoplankton diazotrophy and transfer of nitrogen to picoplankton organisms, Mar. Ecol. Prog. Ser., 343, 25-33.

Gruber, N., and J. Sarmiento (1997), Global patterns of marine nitrogen fixation and denitrification, Global Biogeochem. Cycles, 11, 235-266, doi:10.1029/97GB00077.

Hansell, D. A., and R. A. Feely (2000), Atmospheric intertropical convergence impacts surface ocean carbon and nitrogen biogeochemistry in the western tropical Pacific, Geophys. Res. Lett., 27, 1013-1016, doi:10.1029/1999GL002376.

Holl, C. M., and J. P. Montoya (2005), Interactions between nitrate uptake and $\mathrm{N}_{2}$-fixation in Trichodesmium, J. Phycol., 41, 1178-1183, doi:10.1111/j.1529-8817.2005.00146.x

Hutchins, D. A., F.-X. Fu, Y. Zhang, M. E. Warner, Y. Feng, K. Portune, P. W. Bernhardt, and M. R. Mulholland (2007), $\mathrm{CO}_{2}$ control of Trichodesmium $\mathrm{N}_{2}$ fixation, photosynthesis, growth rates, and elemental ratios: Implications for past, present, and future ocean biogeochemistry, Limnol. Oceanogr., 52, 1293-1304.
Jickells, T. D., et al. (2005), Global iron connections between desert dust, ocean biogeochemistry and climate, Science, 308,67-71, doi:10.1126/ science. 1105959

Karl, D. M. (2002), Nutrient dynamics in the deep blue sea, Trends Microbiol., 10, 410-418, doi:10.1016/S0966-842X(02)02430-7.

Karl, D. M., R. Letelier, L. Tupas, J. Dore, J. Christian, and D. Hebel (1997), The role of nitrogen fixation in biogeochemical cycling in the subtropical North Pacific Ocean, Nature, 388, 533538, doi: $10.1038 / 41474$

Kustka, A. B., E. J. Carpenter, S. Sañudo-Wilhelmy, and W. G. Sunda (2003), Iron requirements for $\mathrm{N}_{2}$ and $\mathrm{NH} 4+$ supported growth in cultures of Trichodesmium (IMS 101), Comparison with nitrogen fixation rates and Fe: $\mathrm{C}$ ratios of field populations, Limnol. Oceanogr., 48, 1869-1884. Langlois, R. J., D. Hümmer, and J. LaRoche (2008), Abundances and distributions of the dominant nifH 4 phylotypes in the northern Atlantic Ocean, Appl. Environ. Microbiol., 74(6), 1922-1931, doi:10.1128/ AEM.01720-07.

Le Bouteiller, A., A. Leynaert, M. R. Landry, R. Le Borgne, J. Neveux, M. Rodier, J. Blanchot, and S. Brown (2003), Primary production, new production and growth rate in the equatorial Pacific: Changes from mesotrophic to oligotrophic regime, J. Geophys. Res., 108(C12), 8141, doi:10.1029/2001JC000914.

Le Moal, M., and I. C. Biegala (2009), Diazotrophic unicellular cyanobacteria in the north western Mediterranean Sea: A seasonal cycle, Limnol. Oceanogr., 54, 845-855.

Mackey, D. J., J. E. O'Sullivan, and R. J. Watson (2002), Iron in the western Pacific, a riverine or hydrothermal source for iron in the Equatorial Undercurrent?, Deep Sea Res., Part I, 49, 877-893, doi:10.1016 S0967-0637(01)00075-9.

Martin, J. H., et al. (1994), Testing the iron hypothesis in ecosystems of the equatorial Pacific Ocean, Nature, 371, 123-129, doi:10.1038/371123a0.

Mazard, S. L., N. J. Fuller, K. M. Orcutt, O. Bridle, and D. J. Scanlan (2004), PCR analysis of the distribution of unicellular cyanobacterial diazotrophs in the Arabian Sea, Appl. Environ. Microbiol., 70, 73557364, doi:10.1128/AEM.70.12.7355-7364.2004.

Mills, M. M., C. Ridame, M. Davey, J. La Roche, and R. J. Geider (2004), Iron and phosphorus co-limit nitrogen fixation in the eastern tropical North Atlantic, Nature, 429, 292-294, doi:10.1038/nature02550.

Montoya, J. P., M. Voss, P. Kaehler, and D. G. Capone (1996), A simple, high precision tracer assay for dinitrogen fixation, Appl. Environ. Microbiol., 62, 986-993.

Montoya, J. P., C. Holl, J. P. Zehr, A. Hansen, T. Villareal, and D. G. Capone (2004), High rates of $\mathrm{N}_{2}$ fixation by unicellular diazotrophs in the oligotrophic Pacific Ocean, Nature, 430, 1027-1032, doi:10.1038/ nature 02824 .

Montoya, J. P., M. Voss, and D. G. Capone (2007), Spatial variation in $\mathrm{N}_{2-}$ fixation rate and diazotroph activity in the tropical Atlantic, Biogeosciences, 4, 369-376.

Moutin, T., N. Van Den Broeck, B. Beker, C. Dupouy, P. Rimmelin, and A. Le Bouteiller (2005), Phosphate availability controls Trichodesmium spp. biomass in the SW Pacific Ocean, Mar. Ecol. Prog. Ser., 297, 1521, doi:10.3354/meps297015.

Needoba, J. A., R. A. Foster, C. Sakamoto, J. P. Zehr, and K. S. Johnson (2007), Nitrogen fixation by unicellular diazotrophic cyanobacteria in the temperate oligotrophic North Pacific Ocean, Limnol. Oceanogr., 52, $3311-3321$

Neveux, J., M. M. B. Tenorio, C. Dupouy, and T. A. Villareal (2006) Spectral diversity of phycoerythrins and diazotroph abundance in tropical waters, Limnol. Oceanogr., 51, 1689-1698.

Peña, M. A., M. R. Lewis, and J. J. Cullen (1994), New production in the warm waters of the tropical Pacific Ocean, J. Geophys. Res., 99, 14,25514,268, doi:10.1029/94JC00603.

Raven, J. A. (1988), The iron and molybdenum use efficiencies of plant growth with different energy, carbon and nitrogen source, New Phytol., 109, 279-287, doi:10.1111/j.1469-8137.1988.tb04196.x.

Rees, A. P., C. S. Law, and E. M. Woodward (2006), High rates of nitrogen fixation during an in-situ phosphate release experiment in the eastern Mediterranean Sea, Geophys. Res. Lett., 33, L10607, doi:10.1029/ 2006GL025791

Sañudo-Wilhelmy, S. A., A. B. Kustka, C. J. Gobler, D. A. Hutchins, M. Yang, K. Lwiza, J. Burns, D. G. Capone, J. A. Raven, and E. J. Carpenter (2001), Phosphorus limitation of nitrogen fixation by Trichodesmium in the central Atlantic Ocean, Nature, 411, 66-69, doi: $10.1038 / 35075041$

Sohm, J. A., C. Mahaffey, and D. G. Capone (2008), Assessment of relative phosphorus limitation of Trichodesmium spp. in the North Pacific and 
Atlantic and the north coast of Australia, Limnol. Oceanogr., 53, 24952502.

Staal, M., F. J. R. Meysman, and L. J. Stal (2003), Temperature excludes $\mathrm{N}_{2}$-fixing heterocystous cyanobacteria in the tropical ocean, Nature, 425 , 504-507, doi:10.1038/nature01999

Tans, P. P., I. Y. Fung, and T. Takahashu (1990), Observational constraints on the global atmospheric $\mathrm{CO}_{2}$ budget, Science, 247, 1431-1439, doi:10.1126/science.247.4949.1431

Toggweiler, J. R., and S. Carson (1995), What are upwelling systems contributing to the ocean's carbon and nutrient budgets?, in Upwelling in the Ocean: Modern Processes and Ancient Records, edited by C. P. Summerhayes et al., pp. 337-360, John Wiley, Hoboken, N. J.

Tréguer, P., and P. Le Corre (1975), Utilisation de l'Autoanalyseur II Technicon. Manuel d'analyses des sels nutritifs dans l'eau de mer, 2ème édition, Laboratoire d'Océanographie chimique, 110 pp., Univ. de Bretagne Occidentale, Brest, France.

Westberry, T. K., D. A. Siegel, and A. Submaranium (2005), An improved bio-optical model for the remote sensing of Trichodesmium spp. blooms, J. Geophys. Res., 110, C06012, doi:10.1029/2004JC002517.

Yoshikawa, C., T. Nakatsuka, and H. Kawahata (2005), Transition of lowsalinity water in the Western Pacific Warm Pool recorded in the nitrogen isotopic ratios of settling particles, Geophys. Res. Lett., 32, L14615, doi:10.1029/2005GL023103.

Yoshikawa, C., Y. Yamanaka, and T. Nakatsuka (2006), Nitrogen isotopic patterns of nitrate in surface waters of the western and central equatoria Pacific, J. Oceanogr., 62, 511-525, doi:10.1007/s10872-006-0072-4.
Zehr, J. P., J. B. Waterbury, P. J. Turner, J. P. Montoya, E. Omoregie, G. F. Steward, A. Hansen, and D. M. Karl (2001), Unicellular cyanobacteria fix $\mathrm{N}_{2}$ in the subtropical North Pacific Ocean, Nature, 412, 635-638, doi:10.1038/35088063.

Zehr, J. P., S. R. Bench, B. J. Carter, I. Hewson, F. Niazi, T. Shi, J. Tripp, and J. P. Affourtit (2008), Globally distributed uncultivated oceanic $\mathrm{N}_{2-}$ fixing Cyanobacteria lack oxygenic photosystem II, Science, 322, 1110 1112, doi: $10.1126 /$ science. 1165340

I. C. Biegala, Centre d'Océanologie de Marseille, Institut de Recherche pour le Développement, UR103 CAMELIA, Rue de la Batterie des Lions F-13007, Marseille CEDEX, France.

S. Bonnet, Laboratoire d'Océanographie, Physique et Biogéochimie, Faculté des Sciences de Luminy, Université de la Méditerranée-AixMarseille II, Institut de Recherche pour le Développement, UR167, CYROCO, CNRS, Case 901, F-13008, Marseille CEDEX, France. (sophie.bonnet@univmed.fr)

D. G. Capone, Wrigley Institute for Environmental Studies, University of Southern California, 3616 Trousdale Parkway, AHF-108, Los Angeles, CA 90089-0371, USA.

P. Dutrieux, SOEST, University of Hawaii, 1000 Pope Road, Honolulu, HI 96822, USA.

L. O. Slemons, School of Oceanography, University of Washington, Box 355351, Seattle, WA 98195-5351, USA. 